\title{
Effect of Drought on Growth and Chlorophyll Content in Three Vetch Species
}

\author{
Sywar Haffani ${ }^{1}$, Majid Mezni ${ }^{2}$ and Wided Chaïbi ${ }^{1}$ \\ ${ }^{1}$ Faculté des Sciences de Tunis, Campus Universitaire, 1060, le Belvédère, Tunisie. \\ ${ }^{2}$ Université de Carthage, Institut National de la Recherche Agronomique de Tunisie, Rue Hédi Karray, 2049 \\ Ariana, Tunisie.
}

\begin{abstract}
Plants in the nature are constantly exposed to biotic and abiotic stresses. Among these stresses, the drought is the mainly important factor unfavorable to the growth and the development of plants, and it is considered as a threat in the sustainable agriculture especially in dry regions. The aim of this work is to study the effect of 4 water regimes [100\% (control) - $80-60$ and $40 \%$ of the field capacity (FC)] on the dimensional and weight growth and on the chlorophyll content in three vetch species (Vicia narbonensis, $V$. sativa and $V$. villosa). The experiment was carried out under greenhouse in a randomized complete block design with four replicates. The sowing was realized by one pre-germinating seed per pot. The water stress was imposed at the two leaves stage. The parameters were determined after 71 days of drought. Results showed that height, leaf area and dry matter of shoots and roots decreased significantly with the water stress intensities on the three vetch species. However, $V$. villosa was the most sensitive one at this stage of growth, compared to Narbonne vetch. The biomass reduction was in concomitance with an important decrease in chlorophyll content which reached $44 \%$ and $20 \%$ respectively for $V$. villosa and $V$. narbonensis.
\end{abstract}

Keywords: Chlorophyll, growth parameters, vetch, water stress.

\section{Introduction}

Vetch (Vicia ssp.) is a leguminous, annual, and commonly used forage in the Mediterranean basin, in pure or in mixture with winter cereal (oat, triticale) under rainfed conditions. The vetch improves the soil fertility and constitutes a good cultural cropping for the wheat (Dalias, 2012). In Tunisia, deficiency in forage and pasture productions is due mainly to the reduction in feed productivity which have been attributed to a decrease in rainfall and consequently an increase in drought frequencies (Chakroun et al., 2011). The major consequences of the climate change for the Mediterranean agriculture is the increase of the risks of drought (Gaufichon et al., 2010; De Oliveira et al., 2012). Indeed, according to Nasr et al., (2009) climate change projections for Tunisia predict, in horizon 2050, a decrease in rainfall around 10 to 30\% from north to south. The drought is widely recognized as the first limiting factor to the agricultural production (Chaves and Oliveira, 2004; Anselm and Taofeeq, 2010.). In these conditions, only the adapted plants can survive. That is the major challenge of the research programs to develop resistant or tolerant varieties to water stress (Almeselmani et al., 2012). Indeed, Sharp et al., (2004) and Tardieu, (2005) signaled that understanding the genetic and the biochemical mechanisms which control drought tolerance is a central question in plant biology and the development of drought-tolerant lines will become increasingly important.

The responses of plant to water deficit are seen through a morphological modifications with a decrease in dry matter and height (Zubaer et al., 2007 ; Oktem, 2008 ; Praba et al., 2009; Nagarajan and Nagarajan, 2010 ; Anjum et al., 2011; Shooshtarian et al., 2011); with a reduction of the leaf expansion which has a consequence in the water losses by stomata and cuticular transpiration (Burghardt and Riederer, 2003; Hufstetler et al., 2007 ; Damour et al., 2010 ; Andivia et al., 2012), with anatomical change (Denden et al., 2005 ; Saadu et al., 2009; Abdel et al., 2011a) and biochemical such as the accumulation of organic compounds (osmoprotectant) like proline, glycine betaïne whose protect proteins and membranes against damage by high concentrations of inorganic ions (Rathinasabapathi, 2000 ; Garg et al., 2001 ; Abebe et al., 2003 ; Akinci and Losel, 2009 ; Akinci and Losel, 2010).

A severe water stress provoked a functional damage and premature senescence of the leaves (Chaves et al., 2002). The main consequences of a water stress are the decrease in the growth caused by a reduced of the photosynthesis (Ashraf et al., 2001). The photosynthesis is the process by which plants combine the water and the $\mathrm{CO}_{2}$ thanks to the energy of the light to synthesize carbohydrates (Brodribb et Holbrook, 2003 ; Dogan et al., 2007 ; Petropoulos et al., 2008).

Tardieu, (2005) resumed the strategies for developing plants able to grow in dry environment scenarios face essentially the same type of choices. Plants can consist in (i) escaping the water deficit, for example by a short crop cycle which allows plants to finish their cycle before severe water stress sets in, (ii) avoiding the water deficit, for instance by reducing transpiration or increasing water uptake, (iii) maintaining growth under 
water deficit, (iv) resisting severe deficit through survival mechanisms. The objective of the present work was to investigate the growth parameters and chlorophyll content in presence or absence of water stress conditions in three vetch species in order to select drought resistant or tolerant genotypes.

\section{Plant material and growth conditions}

\section{Materials and methods}

Four water regimes $[100 \%$ (control) - $80-60$ and $40 \%$ of the field capacity (FC)] were applied on three vetch species: Vicia sativa, V. villosa and V. narbonensis. The experiment was carried out under greenhouse in a randomized complete block design with four replicates ( 3 species $\mathrm{x} 4$ treatments $\mathrm{x} 4$ repetitions $=48$ pots). The sowing was realized by one pre-germinating seed per pot of $16 \mathrm{~cm}$ diameter. The water stress was imposed at the two leaves stage. The parameters were determined after 71 days of drought. The quantity of water requirement for each treatment was determined by mini-lysimètres.

\section{Measurement of parameters}

The growth parameters (plant height, leaf area, dry matter and roots/shoots ratio) were determined after 71 days of water stress. Dry matter of different organs (leaves, stems and roots) was obtained by desiccation at $50^{\circ} \mathrm{C}$. Leaf area was measured for each treatment by photocopying the leaves, cutting leaf footprints, weighing them and then relating this weight to that of a paper of known weight and surface (Mezni et al., 1999; Garcia et al., 2002).

The extraction of chlorophyll was determinate in fourth leaf rank per plant and per replicate. Fresh tissue was sampled from the youngest fully expanded leaf $(1 \mathrm{~g})$, extracted with $80 \%$ acetone and read using a UV/Visible Spectrophotometer at $\lambda=663$ and $\lambda=645 \mathrm{~nm}$ wavelengths. Chlorophyll concentrations (mg.g $\mathrm{g}^{-1}$ DM) were calculated using the formula given by Mackiney (1941): $\boldsymbol{C h l}=\mathbf{2 0 , 2} \boldsymbol{O} \boldsymbol{D}_{\lambda .645}+\mathbf{8 , 0 2} \boldsymbol{O} \boldsymbol{D}_{\lambda .663}$; Were $\mathrm{OD}$ $=$ optical density.

\section{Statistical analysis}

The variance analysis was realized by the software SAS (version 8.0) via ANOVA procedure. The comparison between species and treatments was made with the Duncan test. Confidence intervals were calculated to the threshold of $95 \%$ probability.

\section{Leaf area}

\section{Results}

Leaves constitute the most active organ of the plant. It is the seat of all the biochemical activities. The Figure 1 showed that the leaf area undergoes a significant decrease with the drought intensity for the three vetch species. The severe reduction was observed in V. villosa under the stressful treatment (40\% FC). Compared to villosa and sativa species, $V$. narbonensis was the least affected by the water stress.

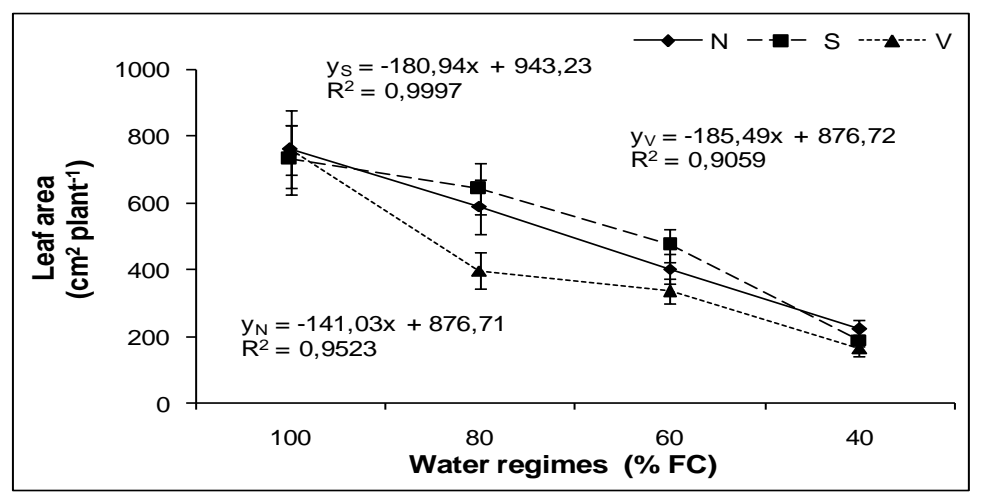

Figure 1. Leaf area of the three vetch species $(\mathrm{N}=$ narbonensis, $\mathrm{S}=$ sativa and $\mathrm{V}=$ villosa $)$ under four water regimes $(100-80-60$ and $40 \% \mathrm{FC})$. Each value represented the mean of 4 replicates. Confidence intervals were calculated at $\alpha=95 \%$ probability level.

\section{Plant height}

Compared to the other species, V. narbonensis had the more important height in absence and presence of the drought. In presence of moderate stress $(80 \% \mathrm{FC})$, the height of $V$. sativa was not significant different with the control (fig. 2). At the stressful treatment $(40 \% \mathrm{FC})$, there is no significant difference for the height between the three species. 


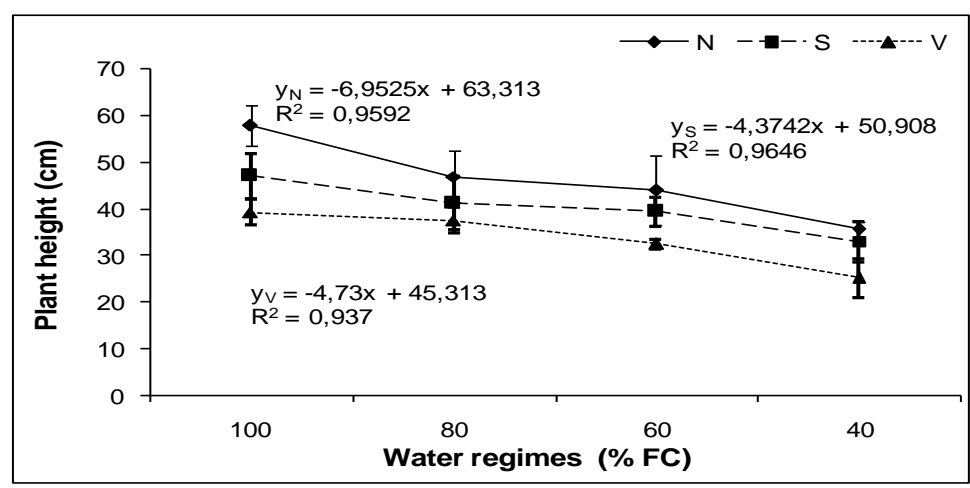

Figure 2. Height of the three vetch species $(\mathrm{N}=$ narbonensis, $\mathrm{S}=$ sativa and $\mathrm{V}=$ villosa $)$ under four water regimes (100 - $80-60$ and 40\%FC). Each value represented the mean of 4 replicates. Confidence intervals were calculated at $\alpha=95 \%$ probability level.

\section{Shoot Dry Matter (DM)}

The dry matter is the resultant of the growth of the height and the carbohydrates accumulation via photosynthesis. The DM was severely reduced by the increase of the water stress intensity for the three vetch species. Shoot DM of $V$. narbonensis was significantly important at the stressful treatments (60 and $40 \% \mathrm{FC})$, where the DR reduction was $53 \%$ under $40 \% \mathrm{FC}$ (fig. 3), compared to $70 \%$ of reduction, respectively for villosa and sativa species, at the same treatment $(40 \% \mathrm{FC})$.

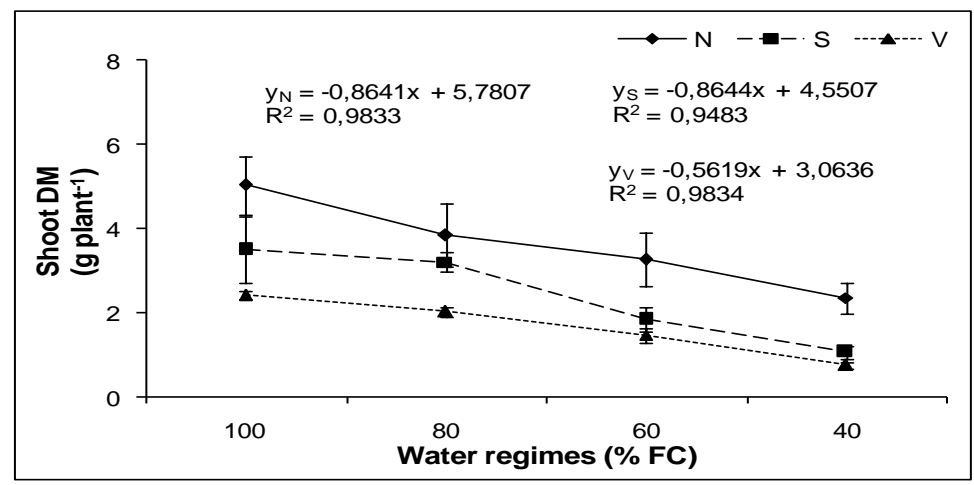

Figure 3. Shoot $\mathrm{DM}$ of the three vetch species $(\mathrm{N}=$ narbonensis, $\mathrm{S}=$ sativa and $\mathrm{V}=$ villosa $)$ under four water regimes (100 - $80-60$ and 40\%FC). Each value represented the mean of 4 replicates. Confidence intervals were calculated at $\alpha=95 \%$ probability level.

\section{Root Dry Matter}

The root dry matter of Narbonne vetch was not affected by the increase of the water stress in pots. While $V$. villosa root DM undergoes a linear reduction with the water stress intensity (fig. 4). For $V$. sativa, the root dry matter was severely reduced by the intensity of the drought (60 and 40\% FC). At the stressful treatment (40\%FC), there is no significant difference between sativa and villosa species.

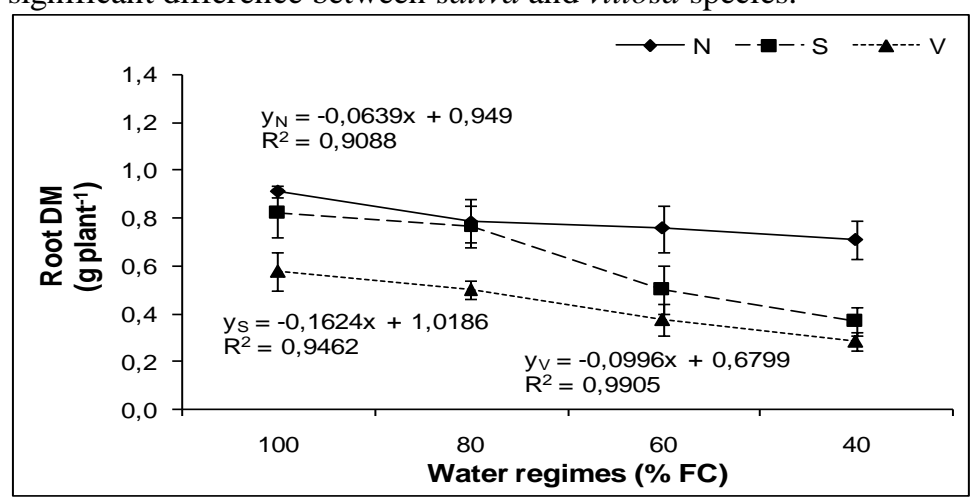

Figure 4. Root DM of the three vetch species $(\mathrm{N}=$ narbonensis, $\mathrm{S}=$ sativa and $\mathrm{V}=$ villosa $)$ under four water regimes (100 - $80-60$ and 40\%FC). Each value represented the mean of 4 replicates. Confidence intervals were calculated at $\alpha=95 \%$ probability level. 


\section{Root/shoot ratio}

The root/shoot ratio of the three vetch species increased with the increase of the intensity of the water stress in pots (fig. 5). This indicated that root DM was less affected by the drought, compared to the shoot DM. Vetch plants developed more roots to investigate a supply of deep horizon of soil.

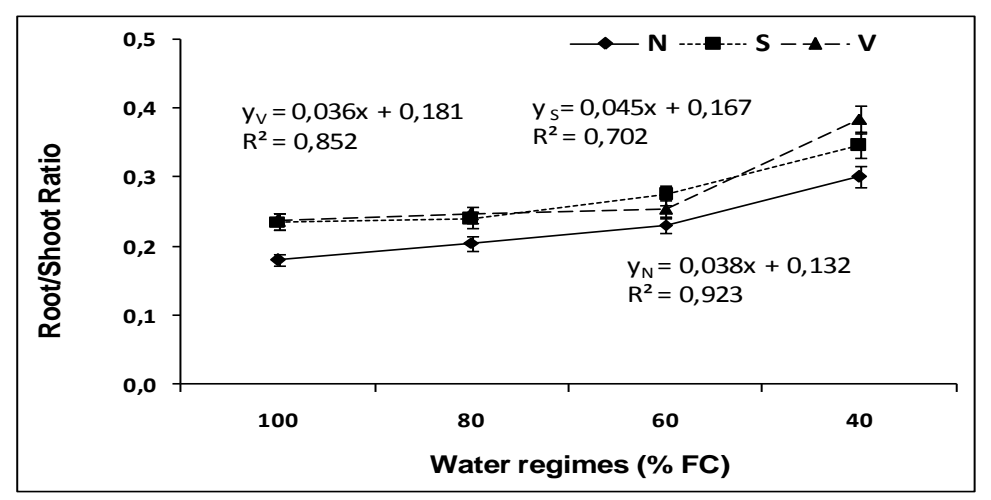

Figure 5. Root/Shoot ratio of the three vetch species $(\mathrm{N}=$ narbonensis, $\mathrm{S}=$ sativa and $\mathrm{V}=$ villosa $)$ under four water regimes (100 - $80-60$ and $40 \% \mathrm{FC}$ ). Each value represented the mean of 4 replicates. Confidence intervals were calculated at $\alpha=95 \%$ probability level.

\section{Chlorophyll content}

$V$. sativa has the high level of the chlorophyll content under all treatments (Fig. 6). The decrease in chlorophyll content for narbonensis and sativa species was not significantly different between the control and the water stressful treatment, while $V$. villosa pigment decrease significantly with the rise of the drought intensity and reached a decrease of $44 \%$ under the stressful treatment $(40 \% \mathrm{FC})$.

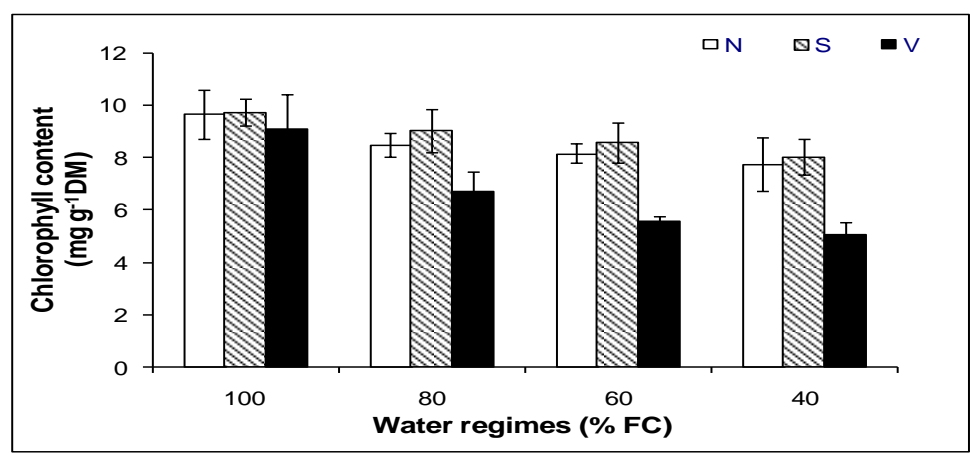

Figure 6. Chlorophyll content of the three vetch species $(\mathrm{N}=$ narbonensis, $\mathrm{S}=$ sativa and $\mathrm{V}=$ villosa $)$ under four water regimes $(100-80-60$ and $40 \% \mathrm{FC})$. Each value represented the mean of 4 replicates. Confidence intervals were calculated at $\alpha=95 \%$ probability level.

\section{Discussion}

In the present study, we investigate the dynamics of the drought through a certain growth parameters of three vetch species. Indeed, the morphological modifications observed on the vetch species under water stress were used as a criterion to tolerate the water deficiency. The most effect of water stress on vetch was the reduction of leaf area, which has a direct consequence in limitation of the water losses by stomatal and cuticular transpiration as mentioned by Noitsakis et al., (1991) and Blum, (2005).

The decrease in vetch LA with the rise of the intensity of water stress confirm the result found by Tardieu, (2005) which he indicated that under drought, if the roots cannot uptake water, the plant slowed down its transpiration by closing stomata and limiting foliar growth. The closure of stomata and the decrease in the foliar growth allowed a homeostasis of the water foliar state, but reduced also the photosynthesis. Prada et al., (2009) observed in two rice cultivars and three wheat varieties subjected to water stress a decrease in the leaf elongation and membrane stability. Indeed, in wheat seedlings subjected to a mild water stress ( $\left.\Psi_{\mathrm{w}}=-0.3 \mathrm{MPa}\right)$, Schuppler et al., (1998) found that the leaf-elongation rate was reduced by one-half and the mitotic activity of mesophyll cells was reduced to $42 \%$ of well-watered controls within 1 day. The leaf area reduction is considered as a criterion of adaptation to the drought (Masinde et al., 2006). However, the decrease of the leaf area in the presence of the water deficit was resulted in a reduction of the dry matter accumulation (Martinielli and Da Silva, 2011). 
Indeed, the water losses on the three vetches pulled a down in guard cell and the closure of stomata (Chaves et al., 2003 ; Sanchez-Blanco et al., 2009). According to Flexa and Medrano, (2002) the inhibition of net photosynthesis under water stress may result in part from lower diffusion of $\mathrm{CO}_{2}$ across leaf mesophyll. Also, an important reduction in the vetch plant height was observed, resulting from a simultaneously inhibition of the cellular division and from a slowing down in the cells elongation of the enter-nodes (Granier et al., 2000 : Costa e Silva et al., 2004 ; Läuchli and Grattan, 2007 ; Martin et al., 2008). Besides, the water deficit reduced the accumulation of the dry matter of the three vetch species, as mentioned by Akmal et al., 2010. This phenomenon was common to most of the cultivated species such as: cowpea (Dadson et al., 2005 ; Lobato et al., 2008 ; Ahmed and Suliman, 2010) ; Rice (Zubaer et al., 2007) ; Soya (Hufstetler et al., 2007 ; Martins et al., 2008 ; Demirtas et al., 2010 ; Makbul et al., 2011) ; alfalfa (Loussaief, 2002 ; Petcu et al., 2009 ; Slama et al., 2011); wheat (Petcu, 2005) ; vetch (Abdel and Al-Rawi, 2011b ; Bilgili et al., 2011 ; Çöçü and Uzun, 2011) and corn (Earl and Davis, 2003).

Our results showed an increase of the root/shoot ratio as was mentioned by Bingcheng et al. (2007) and Slama et al. (2008). This indicated that water stress has entailed a severe decrease in the biomass air part than the root biomass. According to Slama et al., (2006), root/shoot DM ratio is a criterion of plant adaptation to the drought.

This indicated that the plant, in response to water deficit, favors the translocation of assimilats towards roots to investigate a more important of soil volume. Indeed, Achten et al., (2010) indicated in Jatropha curcas, subjected to a severe water stress, that the plant falls its leaves and accumulates more dry matter in roots. Silva et al., (2010) indicated in Erythrina velutina submitted to drought, that the maintenance of turgor pressure seems to be more associated with a reduction in the growth ratio than a reduction in leaf water potential. For Davies (2006), the reduce in soil water availability decreased water uptake by plants and also restricted nutrient uptake by roots and transport to the shoots what in turn reduced the growth.

Besides, several authors showed that the water stress entailed a decrease of the quantity of chlorophyll in leaves (Fu and Huang, 2001 ; Zhang et al., 2007 ; Sanchez-Blanco et al., 2004 ; El Tayeb, 2006 ; Abdalla and El-Khoshiban, 2007 ; Terzi et al., 2010). According to Keyvan (2010), the decrease of the chlorophyll content, in conditions of water deficit, is considered as a non stomatic limiting factor.

\section{Conclusion}

The various growth parameters showed that in absence of a water stress, $V$. narbonensis was characterized with a high LA, height and DM, compared to the other species. In conditions of water stress, $V$. narbonensis was also the most tolerant, followed by $V$. sativa. $V$. villosa was the most affected by water deficit. However, the three vetch species develop their root organs compared to their shoot one to investigate deeper soil horizons and they limit their water losses by a severe reduction in leaf area.

\section{Acknowledgements}

This study was performed within the support of the Faculty of Tunis Science and the Institute of Agronomic Research of Tunis.

\section{Références bibliographiques}

[1] Abdalla M. M., El-Khoshiban N. H., 2007. The influence of water stress on growth, relative water content, photosynthetic pigments, some metabolic and hormonal contents of two Triticum aestivum cultivars. J. Appl. Sci. Res., 3(12): 2062-2074.

[2] Abdel C.G., Al-Rawi I.M.T., 2011a. Anatomical alteration in response to irrigation and water stress in some legume crops. American J. of Exper. Agric., 1(4): 231-264.

[3] Abdel C.G., Al-Rawi I.M.T., 2011b. Common vetch (Vicia sativa L.) response to gibberellic acid application (GA3), supplementary irrigation and its water stress critical stages. Internat. J. of Biosci., 1(3) : 29-38.

[4] Abebe T, Guenzi AC, Martin B, Cushman JC, 2003. Tolerance of mannitol-accumulating transgenic wheat to water stress and salinity. Plant Physiol., 131: 1748-1755.

[5] Achten W.M.J., Maes W.H., Reubens B., Mathijs E., Singh V.P., Verchot L., Muys B., 2010. Biomass production and allocation in Jatropha curcas L. seedlings under different levels of drought stress. Biomass and Bioenergy, 34(5): 667-676.

[6] Ahmed F.E., Suliman A.S.H., 2010. Effect of water stress applied at different stages of growth on seed yield and water-use efficiency of Cowpea. Agric. Biol. J. N. Am., 1(4): 534-540.

[7] Akinci S. and Lösel D. M., 2010. The effects of water stress and recovery periods on soluble sugars and starch content in cucumber cultivars. Fresen. Environ. Bull., 19(2): 164-171.

[8] Akinci S., Losel D.M., 2009. The soluble sugars determination in Cucurbitaceae species under water stress and recovery periods. Advances in Environ. Biol., 3(2): 175-183.

[9] Akmal M., Kausar N., Habib G., Ahmad S., Asim M., Shah N.H., 2010. Yield comparison of forage legumes under partial stress and normal irrigation. Sarhad J. Agric., 26(4): 507-513.

[10] Almeselmani M., Saud A., Al-zubi K., Hareri F., et al., 2012. Physiological Attributes Associated to Water Deficit Tolerance of Syrian Durum Wheat Varieties. Exper. Agric. \& Hort., 21-41.

[11] Andivia E., Carevic F., Fernandez M., Alejano R., Vazquez-Pique’ J., Tapias R., 2012. Seasonal evolution of water status after outplanting of two provenances of Holm oak nursery seedlings. New Forests, 43(5-6): 815-824.

[12] Anjum S.A., Xie X.Y., Wang L.C., Saleem M.F., Man C., Lei W., 2011. Morphological, physiological and biochemical responses of plants to drought stress. Afr. J. of Agric. Res., 6(9): 2026-2032. 
[13] Anselm A. E., Taofeeq A. A., 2010. Challenges of Agricultural Adaptation to Climate Change in Nigeria: a Synthesis from the Literature. Field Actions Sci. Reports, $4: 1-11$.

[14] Ashraf M., Ahmad A., McNeilly T., 2001. Growth and photosynthetic characteristics in pearl millet under water stress and different potassium supply. Photosynthetica, 39(3): 389-394.

[15] Bilgili U., Çarbici E.B., Asik B.B., Çelik N., 2011. Root and shoot response of common vetch (Vicia sativa L.), forage pea (Pisum sativum L.) and canola (Brassica napus L.) to salt stress during early seedling growth stages. Turkish J. of Field Crops, 16(1): 33-38.

[16] Bingcheng X, Lun S, Fengmin L, Jun J, 2007. Seasonal and spatial root biomass and water use efficiency of four forage legumes in semiarid northwest China. African J. of Biotech., 6(23): 2708-2714.

[17] Blum A, 2005. Drought resistance, water-use efficiency, and yield potential - Are they compatible, dissonant, or mutually exclusive? Australian J. of Agric. Res., 56: 1159-1168.

[18] Brodribb T.J., Holbrook N.M., 2003. Stomatal closure during leaf dehydration, correlation with other leaf physiological traits. Plant Physiology, 132: 2166-2173.

[19] Burghardt M., Riederer M., 2003. Ecophysiological relevance of cuticular transpiration of deciduous and evergreen plants in relation to stomatal closure and leaf water potential. J. Exper. Botany, 54(389): 1941-1949.

[20] Chakroun M., Mezni M., Zitouna Chebbi R., 2011. Potential impacts of climatic changes on forage and pasture production in Northern Tunisia. In Contribution of mountain pastures to agriculture and environment. $16^{\text {th }}$ Meeting of the FAO-CIHEAM Mountain pastures Network, 25-27 May 2011; Krakow, Poland: 29-32.

[21] Chaves M.M., Oliveira M.M., 2005. Mechanisms underlying plant resilience to water deficits its: prospects for water-saving agriculture. J. of Exper. Botany, 55(407): 2365-2384.

[22] Chaves M.M., Maroco J.P., Pereira J., 2003. Understanding plant responses to drought from genes to whole plant. Funct. Plant Biol., 30: 239-264.

[23] Chaves M.M., Pereira JS, Maroco J, Rodrigues ML, Ricardo CPP, Osorio ML, Carvalho I, Faria T, Pinheiro C, 2002. How plants cope with water stress in the field. Photosynthesis and growth. Annals of botany, 89: 907-916.

[24] Çöçü S., Uzun O., 2011. Germination, seedling growth and ion accumulation of bitter vetch (Vicia ervilia (L.) Willd. ) lines under $\mathrm{NaCl}$. Afr. J. of Biotech., 10(71): 15869-15874.

[25] Costa e Silva F., Shvaleva A., Maroco J.P., Almeida M.H., Chaves M.M., Pereira J.S. 2004. Responses to water stress in two Eucalyptus globulus clones differing in drought tolerance. Tree Physiology, 24(10): 1165-1172.

[26] Dadson R. B., Hashem F. M., Javaid I ., Joshi J., Allen A. L., Devine T. E., 2005. Effect of water stress on the yield of cowpea (Vigna unguiculata (L.) Walp.) genotypes in the delmarva region of the United States. J. Agron. \& Crop Sci., 191: 210-217.

[27] Dalias P., 2012. Increased Yield Surplus of Vetch-Wheat Rotations under Drought in a Mediterranean Environment. The Sci.World J., 2012: 1-6.

[28] Damour G., Simonneau T., Cochard H., Urban L., 2010. An overview of models of stomatal conductance at the leaf level. Plant, Cell and Environ. 33: 1419-1438.

[29] Davies W.J., (2006). Responses of plant growth and functioning to changes in water supply in a changing climate, In James et al., (Eds.) Plant growth and climate change. 96-117. Blackwell Publishing Ltd, 9600 Garsington Road, Oxford OX4 2DQ, UK.

[30] De Oliveira A.B., Alencar N.L.M., Gomes-Filho E., 2012. Physiological and Biochemical Responses of Semiarid Plants Subjected to Water Stress. In Mofizur Rahman (Ed.), Water Stress, InTech, ISBN: 978-953-307-963-9: 43-58.

[31] Demirtas Ç., Yazgan S., Candogan B.N., Sincik M., Büyükcangaz H., Göksoy A.T., 2010. Quality and yield response of soybean (Glycine max (L.) Merrill) to drought stress in subhumid environment. Afr. J. of Biotech., 9(41): 6873-6881.

[32] Denden M., Bouslama M., Hmida Slimi H., Bouaouina T., 2005 Action du trajet foliaire de diffusion de l'eau et de l'épaisseur de la cuticule sur la transpiration. Sécheresse; 16(2): 125-129.

[33] Dogan E, Kirnak H, Copur O, 2007. Deficit irrigations during soybean reproductive stages and CROPGRO-soybean simulations under semi-arid climatic conditions. Field Crops Res., 103: 154-159.

[34] Earl HJ, Davis RF, 2003. Effect of Drought Stress on Leaf and Whole Canopy Radiation Use Efficiency and Yield of Maize. Agronomy J., 95: 688-696.

[35] El Tayeb M, 2006. Differential Responses of Pigments, Lipid Per-oxidation, Organic Solutes, Catalase and Per-oxidase Activity in the Leaves of Two Vicia faba L. Cultivars to Drought. International J. of Agric. and Biology, 8(1): 116-122.

[36] Flexa J., Medrano H., 2002. Drought-inhibition of photosynthesis in $\mathrm{C}_{3}$ plants: stomatal and non-stomatal limitations revisited. Annals of Botany, 89: 183-190.

[37] Fu J, Huang B, 2001. Involvement of antioxidants and lipid peroxidation in the adaptation of two-cool season grasses to localized drought stress. Environ. and Experim. Botany, 45: 105-114.

[38] Garcia M.G., Busso C.A., Polci P., Garcia Girou N.L., Echenique V., 2002. Water relations and leaf growth rate of three Agropyron genotypes under water stress. Biocell, 26: 309-317.

[39] Garg BK, Kathju S, Burman U, 2001. Influence of water stress on water relations, photosynthetic parameters and nitrogen metabolism of moth bean genotypes. Biol. Plantarum, 44(2): 289-292.

[40] Gaufichon L., Prioul J-L., Bachelier B., 2010. Perspectives d'amélioration génétique de plantes cultivées tolérantes à la sécheresse. Fondation pour l'Agriculture et la Ruralité dans le Monde (FARM), 59p.

[41] Granier Ch., Inzé D., Tardieu F., 2000. Spatial distribution cell division rate can be deduced from that of P34 $4^{\text {cdc2 }}$ kinase activity in maize leaves grown in contrasting conditions of temperature and water status. Plant Physiology, 124: 1393-1402.

[42] Hufstetler E.V., Boerma H.R., Carter T.E., Earl H.J., 2007. Genotypic variation for three physiological traits affecting drou ght tolerance in soybean. Crop Sci., 47: 25-35.

[43] Keyvan S, 2010. The effects of drought stress on yield, relative water content, proline, soluble carbohydrates and chlorophyll of bread wheat cultivars. J. of Animal and Plant Sci., 8(3): 1051-1060.

[44] Läuchli A., Grattan S.R., 2007. Plant growth and development under salinity stress. In M.A. Jenks et al. (eds.), Advances in molecular breeding toward drought and salt tolerant crops, Springer, 1-32.

[45] Lobato A.K.S., Oliveira Neto C.F., Costa R.C.L., Santos Filho B.G., Cruz F.J.R., Laughinghouse IV H.D., 2008. Biochemichal and physiological behavior of Vigna unguiculata (L.) Walp. Under water stress during the vegetative phase. Asian J. of Plant Sci., 7(1): 44-49.

[46] Loussaief L 2002. Etude comparative de l'adaptation à la sécheresse de deux cultivars de Luzerne pérenne (Medicago sativa L.) Gabès et Aquarius, soumis à des cycles répétés de déshydratation. Mémoire de DEA de physiologie végétale, Faculté des Sciences de Tunis.

[47] Mackiney G., 1941. Absorption of light by chlorophyll solution. J. of Biol. and Chemistry, 140: 315-322.

[48] Makbul S., Güler N.S., Durmus N., Güven S., 2011. Changes in anatomical and physiological parameters of soybean under drought stress. Turk. J. Bot., 35: 369-377. 
[49] Martinielli P., Da Silva T.A., 2011. Physiological and bioagronomical aspects involved in growth and yield components of cultivated forage species in Mediterranean environments: a review. European J. of Plant Sci. and Biotech., 5(2): 64-98.

[50] Martins P.K., Jordão B.Q., Yamanaka N., Farias J.R.B., Beneventi M.A., Binneck E., Fuganti R., Stolf R., Nepomuceno A.L., 2008. Differential gene expression and mitotic cell analysis of the drought tolerant soybean (Glycine max L. Merrill Fabales, Fabaceae) cultivar MG/BR46 (Conquista) under two water deficit induction systems. Genetics and Molecular Biology, 31(2): 512-521.

[51] Masinde PW, Stützel H, Agong SG, Fricke A, 2006. Plant growth, water relations and transpiration of two species of African nightshade (Solanum villosum Mill. ssp. Miniatum (Bernh. ex Willd.) Edmonds and S. sarrachoides Sendtn.) under water-limited conditions. Sci. Hortic., 110: 7-15.

[52] Mezni M., Bizid E., Hamza M., 1999. Effets de la salinité des eaux d'irrigation sur la survie et la croissance de trois cultivars de Luzerne pérenne. Fourrages, 158: 169-178.

[53] Nagarajan S., Nagarajan S., 2010. Abiotic Tolerance and Crop Improvement. In Pareek et al., (Eds.). Abiotic stress adaptation in plants. Physiological, molecular and genomic foundation. 1-11. Springer, Netherlands.

[54] Nasr, Z., Almohammed H., Gafrej Lahache R., Maag C., and King L. 2009. Drought modelling under climate change in Tunisia during 2020 and 2050 periods. Options Méditerranéennes, 80: 365-369.

[55] Noitsakis B., Radoglou K.M., Jarvis P.G., 1991. Water relation and growth in two years old seedlings of Medicago arborea under short-time water stress. Phyton, 31(1): 111-120.

[56] Oktem A., 2008. Effect of water shortage on yield, and protein and mineral compositions of drip-irrigated sweet corn in sustainable agricultural systems. Agric. Water Manage., 95(9): 1003-1010.

[57] Petcu E., 2005. The effect of water stress on cuticular transpiration and relationships with winter wheat yield. Romanian Agric. Res., 22: 15-17.

[58] Petcu E., Schitea M., Cîrstea V.E., 2009. The effect of water stress on cuticular transpiration and its association with alfalfa yield. Romanian Agric. Res., 26: 53-56.

[59] Petropoulos SA, Daferera D, Polissiou MG, Passam HC, 2008. The effect of water deficit stress on the growth, yield and composition of essential oils of parsley. Sci. Hortic., 115(4): 393-397.

[60] Praba M.L., Cairns J.E., Babu R.C., Lafitte H.R., 2009. Identification of physiological traits underlying cultivar differences in drought tolerance in rice and wheat. J. of Agron. \& Crop Sci., 195: 30-46.

[61] Rathinasabapathi B., 2000. Metabolic Engineering for Stress Tolerance: Installing Osmoprotectant Synthesis Pathways. Annals of Botany, 86: 709-716.

[62] Saadu R.O., Abdulrahaman A.A., Oladele, F.A., 2009. Stomatal complex types and transpiration rates in some tropical tuber species. African J. of Plant Sci., 3(5): 107-112

[63] Sanchez-Blanco MJ, Alvarez S, Navarro A, Banon S, 2009. Changes in leaf water relations, gas exchange, growth and flowering quality in potted geranium plants irrigated with different water regimes. J. of Plant Physiol., 166(5): 467-476.

[64] Sanchez-Blanco MJ, Ferrandez T, Morales MA, Morte A, Alarcon JJ, 2004. Variation in water stress, gas exchange, and growth in Rosmarinus officinalis plants infected with Glomus deserticola under drought conditions. J. of Plant Physiol., 161: 675-682.

[65] Schuppler U., He P-H., John P.C.L., Munns R., 1998. Effect of water stress on cell division and cell-division-cycle 2-like cell-cycle kinase activity in wheat leaves. Plant Physiol. 117: 667-678.

[66] Sharp R.E., Poroyko V., Hejlek L.G., Spollen W.G., Springer G.K., Bohnert H.J., Nguyen H., 2004. Root growth maintenance during water deficits: physiology to functional genomics. J. of Exper. Botany, 55(407): 2343-2352.

[67] Shooshtarian S., TehraniFar A., Ghani A., Kiani M., 2011. Effects of irrigation frequency regimes on morphological and physiological characteristics of six sedum species. Afr. J. of Agric. Res., 6(26): 5694-5700.

[68] Silva E.C., Silva M.F.A., Nogueira R.J.M.C., Albuquerque M.B., 2010. Growth evaluation and water relations of Erythrina velutina seedlings in response to drought stress. Brazilian J. of Plant Physiol., 22(4): 225-233.

[69] Slama I, Ghnaya T, Savouré A, Abdelly C, 2008. Combined effects of long-term salinity and soil drying on growth, water relations, nutrient status and proline accumulation of Sesuvium portulacastrum. Comptes Rendus Biolog., 331: 442-451.

[70] Slama I, Messedi D, Ghnaya T, Savoure A, Abdelly C, 2006. Effects of water deficit on growth and proline metabolism in Sesuvium portulacastrum. Environ. and Exper. Botany, 56: 231-238.

[71] Slama I., Tayachi S., Jdey A., Rouached A., Abdelly C., 2011. Differential response to water deficit stress in alfalfa (Medicago sativa) cultivars: Growth, water relations, osmolyte accumulation and lipid peroxidation. Afr. J. of Biotech., 10(72): 16250-16259.

[72] Tardieu, F., 2005. Plant tolerance to water deficit: physical limits and possibilities for progress. C. R. Geoscience, 337: 57-67.

[73] Terzi R., Saglam A., Kutlu N., Nar H., Kadioglu A., 2010. Impact of soil drought stress on photochemical efficiency of photosystem II and antioxidant enzyme activities of Phaseolus vulgaris cultivars. Turk. J. Bot., 34: 1-10.

[74] Zhang M., Duan L., Tian X., He Z., Li J., Wang B., Li Z.; 2007. Unicanazole-induced tolerance of soybean to water deficit stress in relation to changes in photosynthesis, hormones and antioxidant system, J. of Plant Physiol., 164(6): 709-717.

[75] Zubaer M.A., Chowdhury A.K.M.M.B., Islam M.Z., Ahmed T., Hasan M.A., 2007. Effects of Water Stress on Growth and Yield Attributes of Aman Rice Genotypes. Int. J. Sustain. Crop Prod., 2(6): 25-30. 